E

51

.1392

vol. 2

no.4

NDIAN NOTES

NMAIREF D MONOGRAPHS

VOL. II

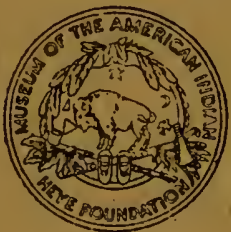

No. 4

A SERIES OF PUBLICATIONS RELATING TO THE AMERICAN ABORIGINES

AN ANTIQUE TOBACCO-POUCH OF THE IROQUOIS

BY

ALANSON SKINNER

NEW YORK

MUSEUM OF THE AMERICAN INDIAN

HEYE FOUNDATION

1920 
Publications of the Museum of the American Indian, Heye Foundation

THE GEORGE G. HEYE EXPEDITION CONTRIBUTIONS TO SOUTH AMER-

ICAN ARCHAEOLOGY

Vol. 1

The Antiquities of Manabi, Ecuador: A Preliminary Report. By Marshall H. Saville. 1907. $\$ 25.00$.

Vol. 2

The Antiquities of Manabi, Ecuador: Final Report. By Marshall H. Saville. 1910. $\$ 25.00$.

CONTRIBUTIONS FROM THE MUSEUM

OF THE AMERICAN INDIAN, HEYE FOUNDATION

\section{Vol. 1}

No. 1: Lucayan Artifacts from the Bahamas. By Theodoor de Booy. Reprinted from Amer. Anthropol., Vol. 15, 1913, No. 1. 50c.

No. 2: Precolumbian Decoration of the Teeth in Ecuador, with some Account of the Occurrence of the Custom in other parts of North and South America. By Marshall H. Saville. Reprinted from Amer. Anthropol., Vol. 15, 1913, No. 3. 50c.

No. 3: Certain Kitchen-middens in Jamaica. By Theodoor de Booy. Reprinted from Amer. Anthropol., Vol. 15, 1913, Yo. 3. (Reprinted, 1919.) 50c.

No. 4: Porto Rican Flbow-stones in the Heye Museum, with discussion of similar objects elsewhere. By J. Walter Fewkes. Reprinted from Amer Anthropol., Vol. 15, 1913, No. 3. $50 \mathrm{c}$. 


\section{INDIAN NOTES \\ AND MONOGRAPHS}

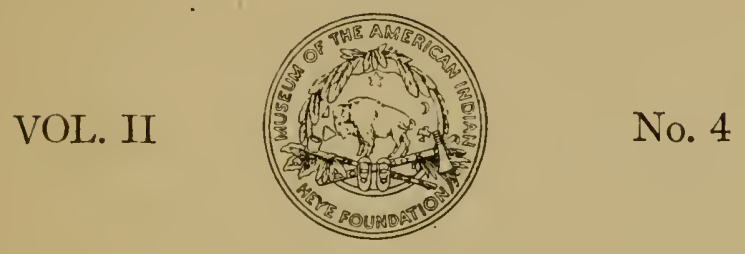

A SERIES OF PUBLICATIONS RELATING TO THE AMERICAN ABORIGINES

\section{AN ANTIQUE TOBACCO-POUCH OF THE IROQUOIS}

BY

ALANSON SKINNER

\section{NEW YORK}

MUSEUM OF THE AMERICAN INDIAN HEYE FOUNDATION 
This series of Indian Notes and MonoGRAPHS is devoted primarily to the publication of the results of studies by members of the staff of the Museum of the American Indian, Heye Foundation, and is uniform with Hispanic Notes and MonografHs, published by the Hispanic Society of America, with which organization this Museum is in cordial coöperation. 
AN ANTIQUE TOBACCOPOUCH OF THE IROQUOIS

\author{
BY \\ ALANSON SKINNER
}






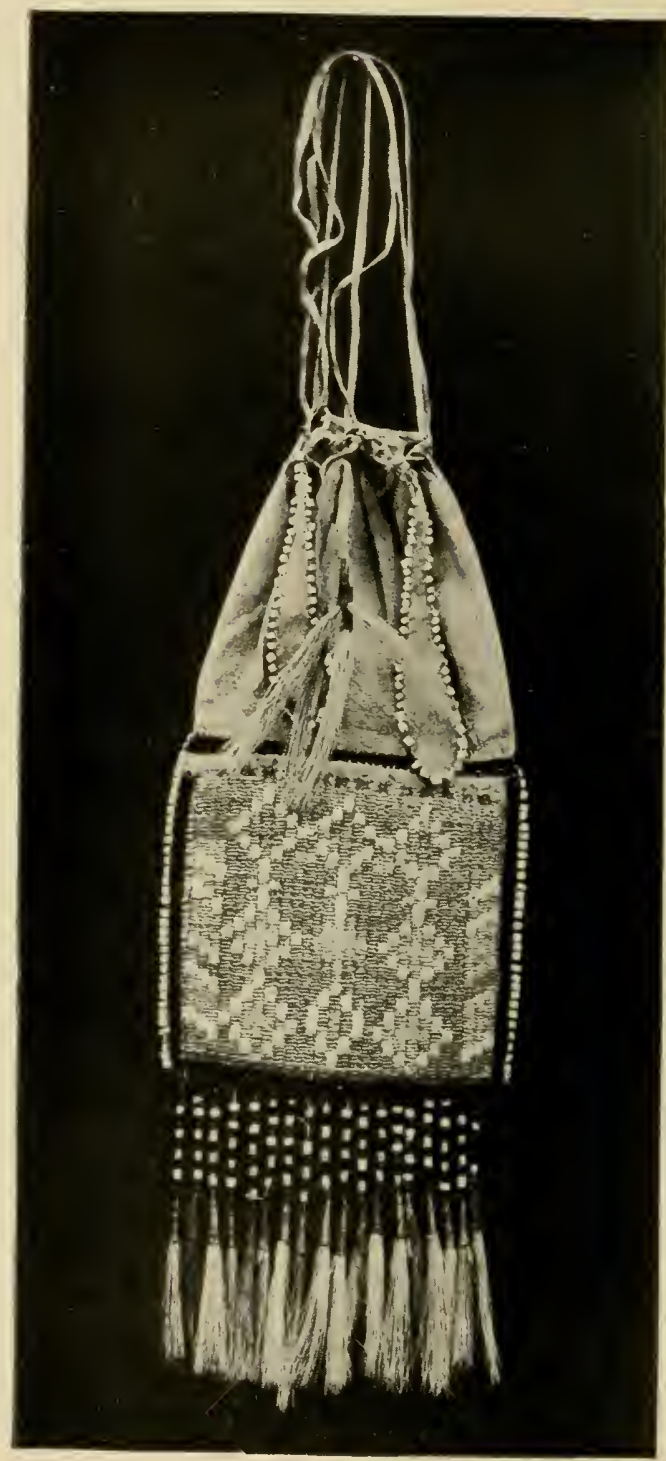

IROQUOIS TOBACCO-POUCH 


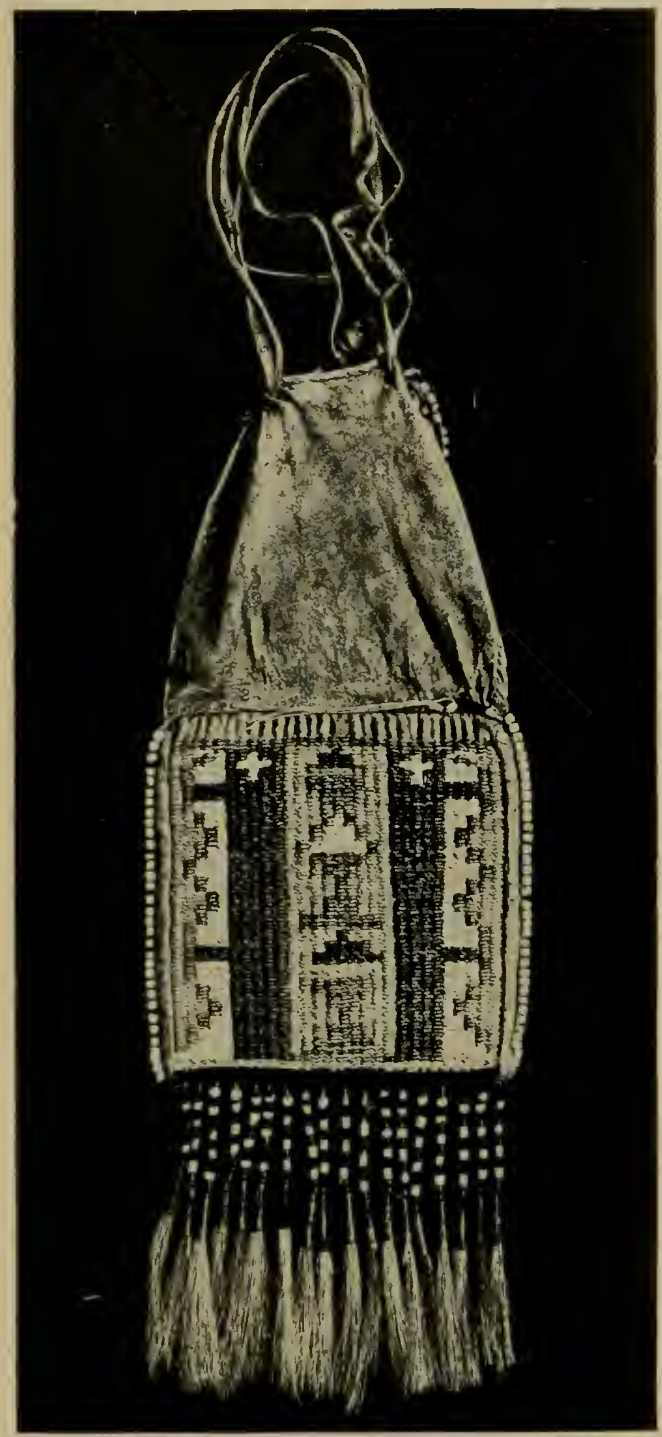

IROQUOIS TOBACCO-POUCH 



\begin{tabular}{|c|c|}
\hline & 107 \\
\hline $\begin{array}{l}\text { AN ANTIQUE TOBACCO-POUCH } \\
\text { OF THE IROQUOIS } \\
\text { By ALANSon SkINNER } \\
\text { a leathern upper portion, with a } \\
\text { bottom of twined woven Indian } \\
\text { ably blanket ravelings. The entire surface } \\
\text { of this part, on both sides, is solidly em- } \\
\text { broidered with dyed deer- or moose-hair in } \\
\text { blue, white, yellow, and red, the red being } \\
\text { faded brown from age, except inside, where } \\
\text { the protruding ends of the hair have not } \\
\text { been exposed to light. The edges of the } \\
\text { bag are adorned with heavy antique opaque } \\
\text { white glass beads. To the bottom are } \\
\text { attached beaded strings with metal jinglers } \\
\text { filled with dyed deer-hair. } \\
\text { The technique and the designs are similar } \\
\text { to those of several ancient Iroquois burden- }\end{array}$ & \\
\hline I NDIAN NOTES & II \\
\hline
\end{tabular}




\begin{tabular}{|l|l|}
\hline 108 & \multicolumn{1}{|c|}{ I R O Q U O I S P O U C H } \\
\hline straps, also in the Museum of the Ameri \\
can Indian, Heye Foundation, so that the \\
provenience of the specimen can be easily \\
determined. This type of work was once \\
known to the Indians of New England as \\
well, for there is a wallet in the collections \\
of the Maine Historical Society which is \\
similar in technique to this specimen and \\
which was obtained from an Abnaki woman \\
about 1785. Of it Mr Willoughby says: \\
"Strictly speaking, the ornamentation is \\
what is termed false embroidery, the outer \\
wool cords being wrapped with moose hair \\
during the process of weaving, and not \\
after the cloth is finished, as in embroidery \\
proper." \\
The bag herein illustrated is 12 inches \\
in length, \\
II \\
I C. C. Willoughby, Textiles of the New Eng- \\
land Indians, American Anthropologist, 1905, \\
n. s., vII, p. 90.
\end{tabular}




No. 5: Note on the Archaeology of Chiriqui. By George Grant MacCurdy. Reprinted from Amer. Anihropol., Vol. 15, 1913, No. 4. $50 \mathrm{c}$.

No. 6: Petroglyphs of Saint Vincent, British West Indies. By 'Thomas Huckerby. Reprinted from Amer. Anthropol., Vol. 16, 1914. No. 2. 50c.

No. 7: Prehistoric Objects from a Shell-heap at Erin Bay, Trinidad. By J. Walter Fewkes. Reprinted from Amer. Anthropol., Vol. 16, 1914, No. 2. 50c.

No. 8: Relations of Aboriginal Culture and Environment in the Lesser Antilles. By J. Walter Fewkes. Reprinted from Bulll. Amer. Geogr. Soc., Vol. 46, 1914, No. 9, 50c.

No. 9: Pottery from Certain Caves in Eastern Santo Domingo, West Indies. By Theodoor de Booy. Reprinted from Amer. Anthropol., Vol. 17, 1915, No. 1 . 50c.

\section{Vol. 2}

No. 1: Exploration of a Munsee Cemetery near Montague, New Jersey: By George G. Heye and George H. Pepper. 1915. \$1.00.

No. 2: Engraved Celts from the Antilles. By J. Walter Fewkes. 1915. 50c.

No. 3: Certain West Indian Superstitions Pertaining to Celts. By Theodoor de Booy. Reprinted from Journ. Amer. Folk-Lore, Vol. 28, No. 107, 1915 . 50c.

No. 4: The Nanticoke Community of Delaware. By Frank G. Speck. 1915. \$1.00.

No. 5: Notes on the Archeology of Margarita Isiand, Venezuela. By Theodoor de Booy. 1916. 50c.

No. 6: Monolithic Axes and their Distribution in Ancient America. By Marshall H. Saville. 1916. 50c. 


\section{Vol. 3}

Physical Anthropology of the Lenape or Delawares, and of the Eastern Indians in General. By Aleš Hrdlička. (Bur. of Amer. Ethnol., Bull. 62, 1916, with added title-page and cover.) $\$ 1.00$.

\section{Vol. 4}

No. 1: The Technique of Porcupine-Quill Decoration among the North American Indians. By William C. Orchard. 1916. \$1.00.

No. 2: Certain Archeological Investigations in Trinidad, British West Indies. By Theodoor de Booy. Reprinted from Amer. Anthropol., Vol. 19, 1917, No. 4. 50c.

No. 3: The Nacoochee Mound in Georgia. By George G. Heye, F. W. Hodge, and George H. Pepper. 1918. $\$ 1.50$.

\section{Vol. 5}

No. 1: A Letter of Pedro de Alvarado Relating to his Expedition to Ecuador [1534]. By Marshall H. Saville. 1917. 50c.

No. 2: The Diegueño Ceremony of the DeathImages. By E. H. Davis. 1919. 50c.

No. 3: Certain Mounds in Haywood County, North Carolina. By George G. Heye. Reprinted from Holmes Anniversary Volume, 1916. 1919. 50c.

No. 4: Exploration of Aboriginal Sites at Throgs Neck and Clasons Point, New York City. By Alanson Skinner. 1919. \$1.00.

Address :

MuseuM OF THE AMLERCAN INDIAN, Heye

FOUNDATION,

BroadWAy at $155 \mathrm{TH}$ Sr.,

NEW YORK CITY 